\title{
The value of hydrocarbon-grown yeast as a source of protein for growing pigs
}

\author{
By R. S. BARBER, R. BRAUDE, K. G. MITCHELL AND A. W. MYRES \\ National Institute for Research in Dairying, Shinfield, Reading $R G 29 A T$
}

(Received I6 fune 1970-Accepted 2 October 1970)

\begin{abstract}
I. The yeast grown on normal paraffins (British Petroleum Proteins Ltd, London) contained $62 \%$ crude protein and, except for lower content of methionine, its amino acid composition was similar to that of white fish meal.

2. The value to growing pigs of yeast + methionine as a protein supplement to diets based on barley and fine wheat offal was compared with that of white fish meal. The two protein supplements supplied the same amount of total nitrogen and were compared at a 'standard' level, commonly used in practice, and at a 'low' level. Two experiments were conducted: a feeding trial covering the live-weight range from 20 to $90 \mathrm{~kg}$, and a metabolic trial $(20-60 \mathrm{~kg}$ live weight) in which $\mathrm{N}$ retention and digestibility were measured.

3. There was a small but significant difference in favour of the yeast treatment for growth rate and feed conversion ratio, but there were no consistent differences in the linear measurements of the carcasses due to protein source.

4. In the metabolic trial there was no significant difference in performance, $\mathbf{N}$ retention, apparent $\mathrm{N}$ digestibility or linear carcass measurements and no consistent difference in tissue components, between the diets supplemented with yeast or fish meal.

5. In pigs given the 'low'-protein diets, performance and most of the other variables measured were significantly poorer than in those given the 'standard' protein diets, irrespective of whether yeast or fish meal was the source of supplementary protein.

6. It is concluded that yeast ( + methionine) may be closely equated with high-quality fish meal as a protein supplement in diets for growing pigs. The small differences found are discussed in relation to possible differences in availability of amino acids and energy values in the diets.
\end{abstract}

In recent years, increasing attention has been paid to the problem of the world shortage of protein, and particularly of high-quality protein of animal origin. A search for new sources led to the development of the BP protein concentrate which is a yeast grown on hydrocarbons obtained from oil.

The hydrocarbons provide the energy source for the yeast and, in the two processes so far developed, they are either in the form of heavy 'gas oil' or are normal paraffins of high purity (Shacklady, $1969 a, b$ ). The yeast used in the experiments reported here was grown on the paraffin medium. According to Shacklady (1969b), the two yeast products differ in total crude protein and total lipid contents, $68-70$ and $63-65 \%$ for crude protein and approximately $\mathrm{I}_{5} 5$ and $9 \%$ for lipids for the products grown on 'gas oil' and paraffin respectively; the total amino acid composition of both products expressed per $\mathrm{I} 6 \mathrm{~g}$ nitrogen is very similar to that in white fish meal. Using the 'gas oil' product, van der Wal, Shacklady \& van Weerden (I969) reported preliminary results of long-term trials with breeding, sucking and growing pigs which indicated that the performance of pigs given the diets supplemented with yeast (+ methionine) compared well with that of pigs given diets supplemented with fish meal. The diets used contained more total crude protein than is normally recommended. 
The object of the experiments now described was to assess the value of yeast grown on a paraffin medium when the protein intake was lower and to obtain information both on performance and on $\mathrm{N}$ balance and carcass composition.

\section{EXPERIMENTAL}

\section{Treatment and diets}

In the two experiments, one a feeding and the other a metabolic trial, the yeast with added methionine was compared with white fish meal as a protein supplement in diets containing barley meal and fine wheat offal as the cereal base. The comparison was made at two levels of supplementation: a 'standard' level, as normally used in our

\section{Table r. Percentage compositirn of the experimental diets for treatments $\mathrm{I}-4$}

\begin{tabular}{|c|c|c|c|c|c|c|c|c|}
\hline \multirow[b]{3}{*}{ Ingredient } & \multicolumn{4}{|c|}{ Up to $60 \mathrm{~kg}$ live weight } & \multicolumn{4}{|c|}{$\begin{array}{c}\text { From } 60 \mathrm{~kg} \text { live weight } \\
\text { to slaughter }\end{array}$} \\
\hline & \multicolumn{2}{|c|}{ 'Standard' level } & \multicolumn{2}{|c|}{ 'Low' level } & \multicolumn{2}{|c|}{ 'Standard' level } & \multirow{2}{*}{$\overbrace{3}^{\text {'Low' }}$} & \multirow{2}{*}{$\frac{\text { level }}{4}$} \\
\hline & $\mathbf{I}$ & 2 & 3 & 4 & $\mathbf{I}$ & 2 & & \\
\hline eal offal & $\begin{array}{l}71 \cdot 25 \\
20 \cdot 00\end{array}$ & $\begin{array}{l}70 \cdot 96 \\
20 \cdot 00\end{array}$ & $\begin{array}{l}74 \cdot 78 \\
20 \cdot 00\end{array}$ & $\begin{array}{l}74 \cdot 56 \\
20 \cdot 00\end{array}$ & $\begin{array}{l}75 \cdot 19 \\
20 \cdot 00\end{array}$ & $\begin{array}{l}74 \cdot 89 \\
20 \cdot 00\end{array}$ & $\begin{array}{l}76 \cdot 97 \\
20 \cdot 00\end{array}$ & $\begin{array}{l}76 \cdot 80 \\
20 \cdot 00\end{array}$ \\
\hline on-grown yeast & - & $7 \cdot 10$ & - & $3 \cdot 10$ & - & $3 \cdot 62$ & - & I.55 \\
\hline meal & $\begin{array}{l}7 \cdot 00 \\
0.27\end{array}$ & $\overline{0.38}$ & $\begin{array}{l}3.00 \\
0.27\end{array}$ & $\overline{0.38}$ & $\begin{array}{l}3.50 \\
0.27\end{array}$ & $\overline{0.38}$ & $\begin{array}{l}x \cdot 50 \\
0.27\end{array}$ & $\overline{0.38}$ \\
\hline aydrogen phosphate* & 0.56 & - & $x \cdot 35$ & 1.05 & 0.22 & - & 0.58 & 0.44 \\
\hline plement† & $\begin{array}{l}0.62 \\
0.20\end{array}$ & $\begin{array}{l}I \cdot 20 \\
0 \cdot 20\end{array}$ & $\begin{array}{l}0.30 \\
0.20\end{array}$ & $\begin{array}{l}0.58 \\
0.20\end{array}$ & $\begin{array}{l}0.52 \\
0.20\end{array}$ & $\begin{array}{l}0.78 \\
0.20\end{array}$ & $\begin{array}{l}0.38 \\
0.20\end{array}$ & $\begin{array}{l}0.52 \\
0.20\end{array}$ \\
\hline $\begin{array}{l}\text { ulphate } \\
\text { onine }\end{array}$ & 0.10 & $\begin{array}{l}0.10 \\
0.06\end{array}$ & 0.10 & $\begin{array}{l}0.10 \\
0.03\end{array}$ & 0.10 & $\begin{array}{l}0.10 \\
0.03\end{array}$ & 0.10 & $\begin{array}{l}0.10 \\
0.01\end{array}$ \\
\hline
\end{tabular}

* See this page.

† Cooper Nutrition Products Ltd, containing in $2 \mathrm{~kg}: 2.5 \times 10^{8}$ i.u. vitamin A, 300000 i.u. cholecalciferol $3.25 \mathrm{~g}$ riboflavin, $15.75 \mathrm{~g}$ nicotinic acid, $13.00 \mathrm{~g}$ pantothenic acid, $3.25 \mathrm{~g}$ pyridoxine, $13 \mathrm{mg}$ vitamin $B_{12}, 200 \mathrm{~g}$ choline, $2 \mathrm{~g}$ DL- $\alpha$-tocopheryl acetate.

control diets, and an arbitrary 'low' level. Table I gives the percentage composition of the experimental diets. In Expt I the amounts of both protein supplements were halved after the pigs reached $60 \mathrm{~kg}$ live weight. All diets were supplemented with copper sulphate to provide $250 \mathrm{mg} \mathrm{Cu} / \mathrm{kg}$ diet, and DL-methionine was added to the yeast diets in order to make the content of this amino acid similar to that in the fishmeal diet; previous reports suggested that methionine may be a limiting amino acid in diets containing such yeasts. Table 2 gives the amino acid composition and Table 3 the chemical composition of the two protein supplements and also of all the experimental diets.

It was intended to have calcium and phosphorus levels in all diets as similar as possible, and the mineral supplements were added in the amounts given in Table $\mathbf{I}$ to augment the $\mathrm{Ca}$ and $\mathrm{P}$ supplied by the ingredients. After the completion of the test it was found that two of the analytical values for $\mathrm{Ca}$ and $\mathrm{P}$ were incorrect. The errors were considered to be of little consequence and the values given in Table 3 were subsequently calculated using the corrected values. 


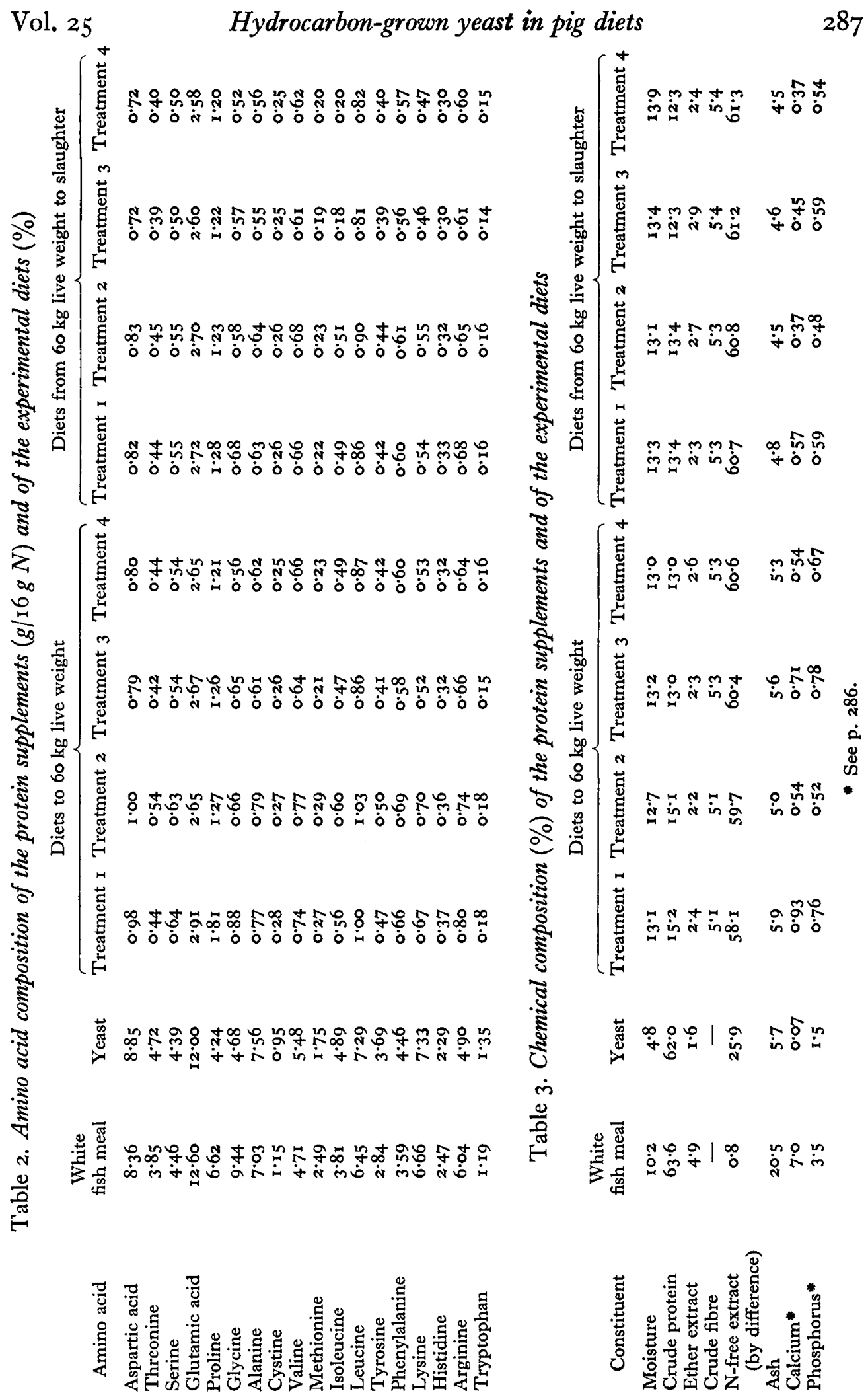




\section{Pigs and experimental procedure}

Both experiments were of randomized block design; in the feeding trial (Expt I) ten blocks, and in the metabolic trial (Expt 2) six blocks, were used, each consisting of four litter-mate pigs, 9-1o weeks old, of similar initial weight, from the Shinfield enzootic pneumonia-free Large White herd. In Expt I a similar number of castrated males and females was used on all treatments; in Expt 2 all pigs were castrated males.

In Expt $\mathrm{I}$ the pigs were housed in groups of four or six in pens equipped for individual feeding and there was no direct communication between pigs on different treatments. In Expt 2 the pigs were penned individually in a centrally heated house (thermostat set at $16^{\circ}$ ). All pigs were fed twice daily.

In both experiments the pigs were weighed once weekly and rationed according to the Shinfield scale (Braude \& Mitchell, I95 $x$ ), based on live weight. The meal was mixed with water, immediately before being offered, at a rate of $2 \cdot 51$ water $/ \mathrm{kg}$ meal.

In Expt $\mathrm{I}$ the pigs were sent to slaughter when they weighed $90 \mathrm{~kg}$, and in Expt 2 when they weighed $60 \mathrm{~kg}$. At slaughter, measurements on the split carcass were taken, together with measurements on the surface exposed by cutting through the carcass at the level of the last rib by the methods described by Buck, Harrington \& Johnson (1962). In Expt 2 the headless left side of each carcass, including flare fat, fillet muscle, kidney and feet, was dissected into lean, fat and bone by the technique described by Cuthbertson \& Pomeroy (1962).

\section{Determination of $N$ balance}

During the ist week the pigs gradually changed to the experimental diets, and were placed for short periods each day in metabolism crates to accustom them to the experimental routine. The crates used were described in detail by Braude \& Mitchell (I964).

Over the growing period from 20 to $60 \mathrm{~kg}$ live weight, at intervals of approximately 3 weeks, the pigs were put into the crates for a $5 \mathrm{~d}$ collection period; there were four such periods for each animal.

Faeces were collected twice daily and stored at $4^{\circ}$ in tightly sealed polyethylene bags. At the end of each collection period the bulked faeces for each pig were weighed and thoroughly mixed in a Hobart mixer; a representative sample was taken into a sealed polyethylene bottle for subsequent $\mathrm{N}$ determination. Urine was collected in large polyethylene flasks containing $25 \mathrm{ml}$ glacial acetic acid as a preservative; once daily the volume of urine was measured and a $10 \%$ sample was taken and stored at $4^{\circ}$ in a screw-capped polyethylene bottle. At the end of each collection period a sample from the bulked daily samples of each pig was taken for $\mathrm{N}$ determination.

Feed losses due to spillage were minimized by placing a drip tray under the feeding trough and returning any spilled feed to the trough.

\section{Analytical methods}

$N$ determination. Samples were dissolved in $2 \mathrm{ml}$ conc. sulphuric acid and a catalyst mixture consisting of $1.2 \mathrm{~g}$ anhydrous potassium sulphate (Analar grade) and $0.05 \mathrm{~g}$ mercuric oxide. Each digest was diluted with distilled water so as to contain $\mathrm{I}-\mathrm{I} 5 \mathrm{mg}$ 
$\mathrm{N} / \mathrm{r} 00 \mathrm{ml}$. $\mathrm{N}$ concentration was measured with a Technicon AutoAnalyzer (Technicon Instruments Co. Ltd, Chertsey, Surrey).

Amino acid determination. For the low-protein ingredients of the diets (barley and wheat offal), about I $\mathrm{g}$ finely ground material was weighed into a I 1 round-bottomed flask. To it were added $45^{\circ} \mathrm{ml} 6 \mathrm{~N}-\mathrm{HCl}$ and the mixture was heated on an oil-bath $\left(120^{\circ}\right)$ for $24 \mathrm{~h}$. For the high-protein ingredients (yeast and fish meal), about $0.5 \mathrm{~g}$ was weighed and treated in the same way. The following day, the solutions were filtered through Whatman no. 540 filter-paper into a $500 \mathrm{ml}$ volumetric flask and made up to volume. A portion was then taken $(5 \mathrm{ml}$ for the high-protein and $\mathrm{ro} \mathrm{ml}$ for the lowprotein ingredients) and evaporated to dryness in a rotary evapor ator. The residue was dissolved in $5 \mathrm{ml}$ sodium citrate buffer, $\mathrm{pH} 2 \cdot 2$, just before analysis. The amino acids were determined by the procedure described by Moore, Spackman $\&$ Stein (1958) and Spackman, Stein \& Moore (1958) using ion-exchange chromatography and a multichannel amino acid analyser (Evans Electroselenium Ltd, Halstead, Essex).

Cystine and cysteine cannot be determined satisfactorily after acid hydrolysis since they are partly oxidized to cysteic acid. They were measured by the method of Moore (1963), involving complete oxidation with performic acid to cysteic acid and estimation of the product by ion-exchange chromatography. The area under the curve on the chromatogram was compared with that obtained with a known amount of cysteic acid.

DNA and RNA content of the hydrocarbon-grown yeast and the white fish meal was measured by the method described by McAllan \& Smith (1969).

\section{RESULTS}

Expt I

Mean values and appropriate standard errors for daily live-weight gain, feed conversion ratio and carcass measurements are given in Table 4, together with the results of tests of significance.

There was a tendency for pigs on the yeast diets to perform slightly better than pigs on the fish-meal diets, the difference being more pronounced at the 'standard' level of supplementation.

There was a highly significant difference in performance between pigs given the diets containing the 'standard' level and those containing the 'low' level of protein supplement, independently of whether the protein supplement was yeast or fish meal.

Differences between results with the two protein supplements were not significant for any of the carcass measurements other than eye muscle length. However, most of the differences between results with the 'standard' and the 'low' levels of protein were significant, indicating that there was less lean and more fat in the carcasses of pigs given the diets with a lower protein content, irrespective of protein source.

\section{Expt 2}

Table 5 summarizes the results for daily live-weight gain, feed conversion ratio, total $\mathrm{N}$ retained and apparent digestibility of $\mathrm{N}$. The covariance of $\mathrm{N}$ retention on initial live weight was significant, and the treatment means were accordingly adjusted 
290 R. S. Barber, R. Braude, K. G. Mitchell and A. W. Myres I97I

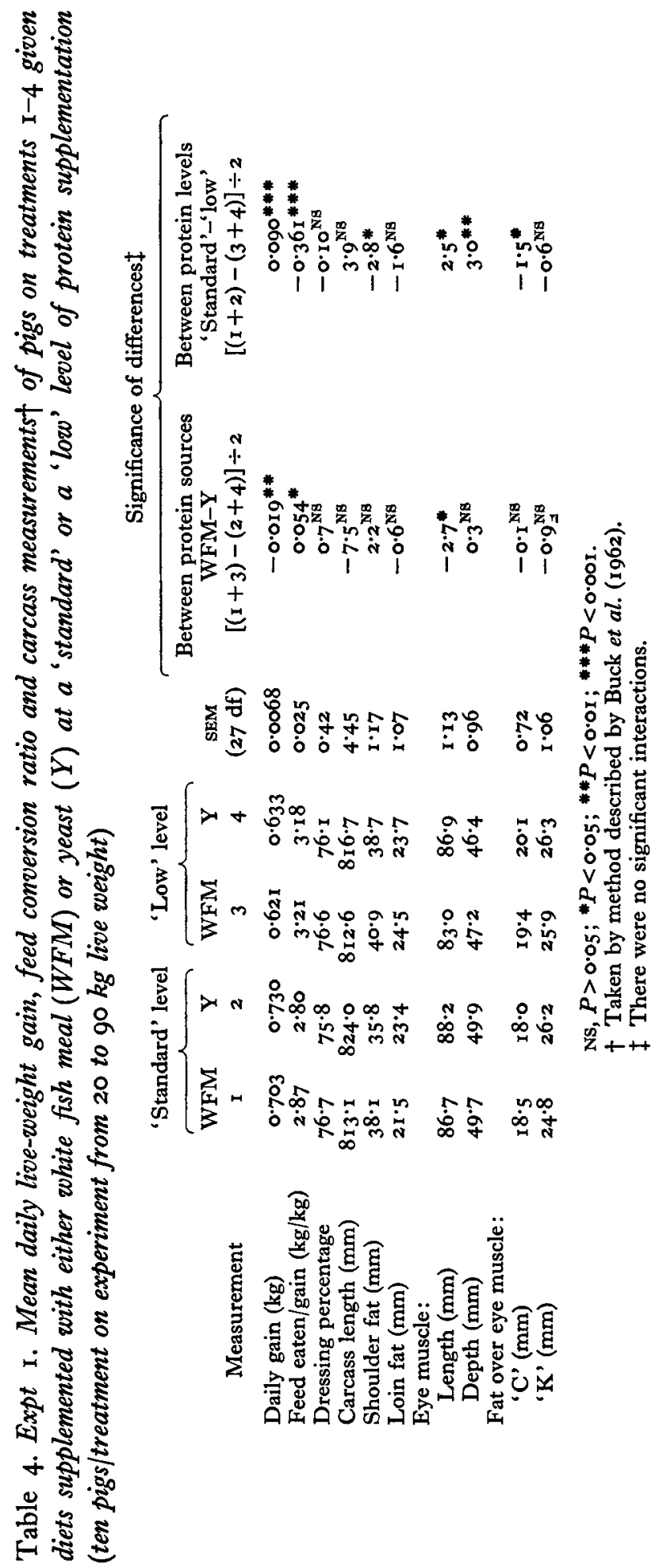


Vol. 25

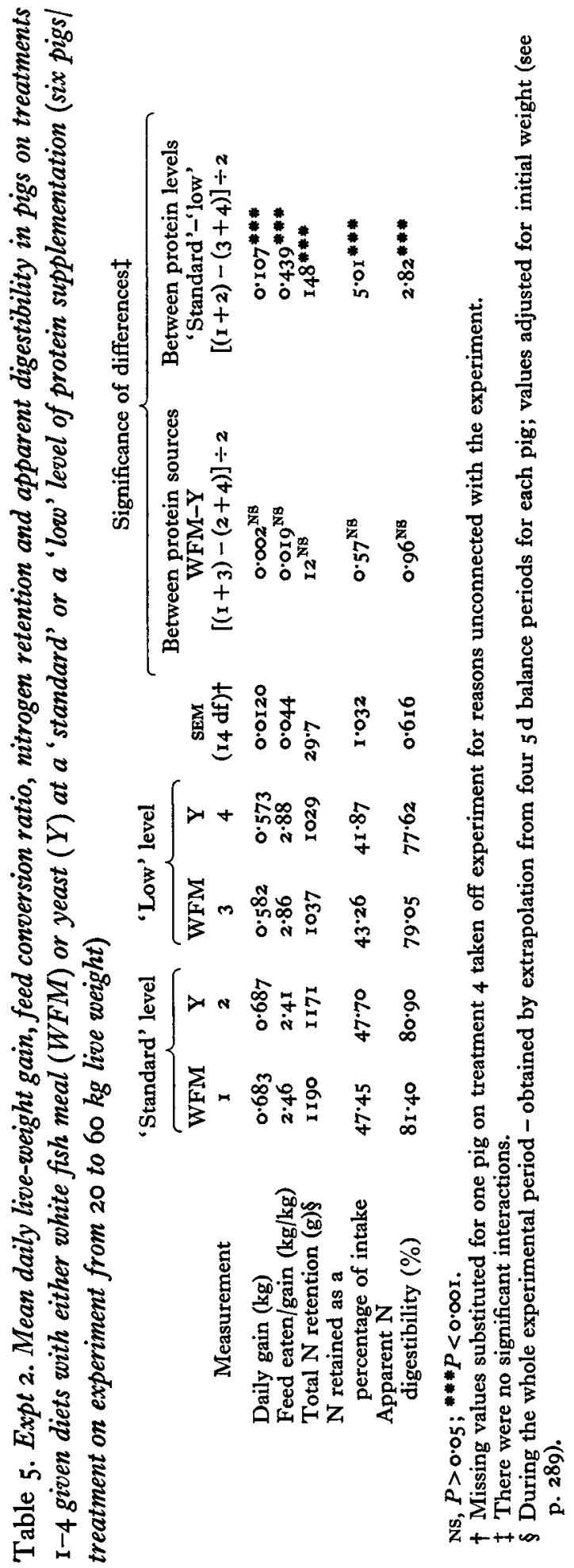


292 R. S. Barber, R. Braude, K. G. Mitchell and A. W. Myres i97I

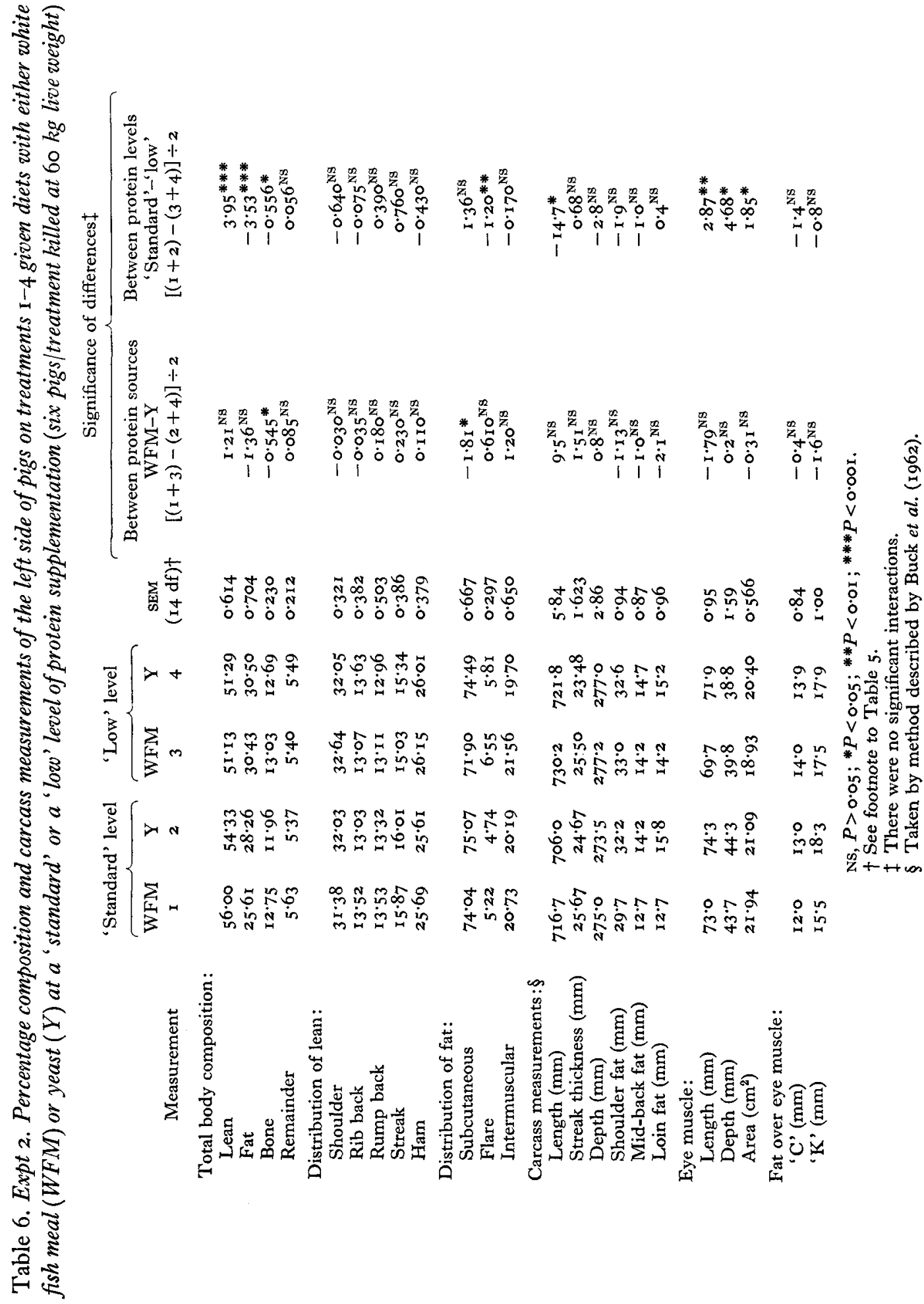


for initial live weight. There were no significant covariance relations between any of the other variables and initial weight.

There were no significant differences due to source of protein supplement, but for all the values shown in Table 5 , those for the pigs given the diets with the 'standard' level of protein supplement were significantly superior to those for the pigs given the diets with the 'low' level of protein supplement, irrespective of source of protein supplement.

The results of the dissection studies, summarized in Table 6, show that there were significant differences between treatments in body composition, but again these were mainly the result of different amounts of protein in the diet, carcasses of pigs given the diets supplemented at the 'standard' level having more lean and less fat than those of pigs given the 'low'-protein diets. However, in addition, the carcasses of pigs that had received yeast contained significantly more subcutaneous fat and less bone than the carcasses of pigs given fish meal.

There were no significant differences due to protein source between any of the carcass measurements shown in Table 6 . The carcasses of pigs given the protein supplement at the 'standard' level were significantly shorter and had a larger eye muscle than those of pigs given the supplement at the 'low'-protein level.

Determination of RNA and DNA showed that together they accounted for approximately $10 \%$ of the total $\mathrm{N}$ in the hydrocarbon-grown yeast, which compared with a value of only about I \% in the fish meal.

\section{DISCUSSION}

From the results of the two experiments, it may be concluded that, in general, paraffin-grown yeast (+methionine) and white fish meal are equally effective as protein supplements in cereal-based diets for growing pigs. The results are in good agreement with those obtained by van der Wal et al. (1969) in experiments in which they fed growing pigs on diets containing appreciably higher levels of total protein than are normally recommended. It is of interest that, in a number of the comparisons between gas-oil-grown yeast ( + methionine) and fish meal, reported by these workers, there was a small difference in performance in favour of the pigs receiving the yeast, similar to that observed by us in Expt I. Whether such small differences are real treatment effects cannot yet be assessed; it is possible that they are associated with the differences in amino acid availability between the two protein sources, discussed below, or alternatively with small differences in the energy values of the diets being compared. Some results indicating the metabolizable energy of hydrocarbon-grown yeast for pigs to be somewhat higher than that of fish meal have been given by van der Wal et al. (1969), but it should be borne in mind that, in the relatively small amounts added to the complete diets, any difference in energy between the two protein supplements would need to be of considerable magnitude if the energy value of the complete diets was to be markedly affected.

Microbial cells contain more non-protein $\mathrm{N}$ in the form of nucleic acids than do most conventional protein sources, and RNA and DNA comprised about $10 \%$ of the total 


\section{R. S. Barber, R. Braude, K. G. Mitchell and A. W. Myres i97i}

$\mathrm{N}$ in the hydrocarbon-grown yeast, whereas they contributed only $\mathrm{I} \%$ in the fish meal. Despite the resulting lower true protein content of the yeast-containing diet, its total content of essential amino acids compared favourably with that of the fish-meal diet. Furthermore, the availability of the amino acids in the yeast protein used in our test was exceptionally high as judged in microbiological tests, 90-95\%, as against $80-85 \%$ availability commonly observed for white fish meal in this Institute (J. E. Ford, private communication).

Our grateful thanks are due to Mr C. A. Shacklady of B.P. Proteins Ltd, Britannic House, London, EC2, for supplying the hydrocarbon-grown yeast, to $\mathrm{Mr}$ A. Cuthbertson, of the Meat and Livestock Commission, Stotfold, for the carcass dissections, and to our colleagues, Mr A. B. McAllan, for the determination of DNA and RNA and Mr M. R. Jones for help with the statistical analysis. A Postgraduate Scholarship awarded to one of us (A. W. M.) by the Meat and Livestock Commission is gratefully acknowledged.

\section{REFERENCES}

Braude, R. \& Mitchell, K. G. (I95I). Agriculture, Lond. 57, 501.

Braude, R. \& Mitchell, K. G. (1964). F. Anim. Techns Ass. 15, 71.

Buck, S. F., Harrington, G. \& Johnson, R. F. (1962). Anim. Prod. 4, 25.

Cuthbertson, A. \& Pomeroy, R. W. (1962). F. agric. Sci., Camb. 59, 207.

McAllan, A. B. \& Smith, R. H. (1969). Br. F. Nutr. 23, 67г.

Moore, S. (1963). F. biol. Chem. 238, 235 .

Moore, S., Spackman, D. E. \& Stein, W. H. (1958). Analyt. Chem. 30, 1185.

Shacklady, C. A. (1969a). New Scient. 43, no. 668, p. 5 .

Shacklady, C. A. (1 969b). Proc. Nutr. Soc. 28, 9 1.

Spackman, D. H., Stein, W. H. \& Moore, S. (1958). Analyt. Chem. 30, 190.

van der Wal, P., Shacklady, C. A. \& van Weerden, E. J. (1969). Proc. int. Congr. Nutr. viIr. Prague p. V-3. 